\title{
Envisioning dystopia: Eben Venter's Art of Darkness
}

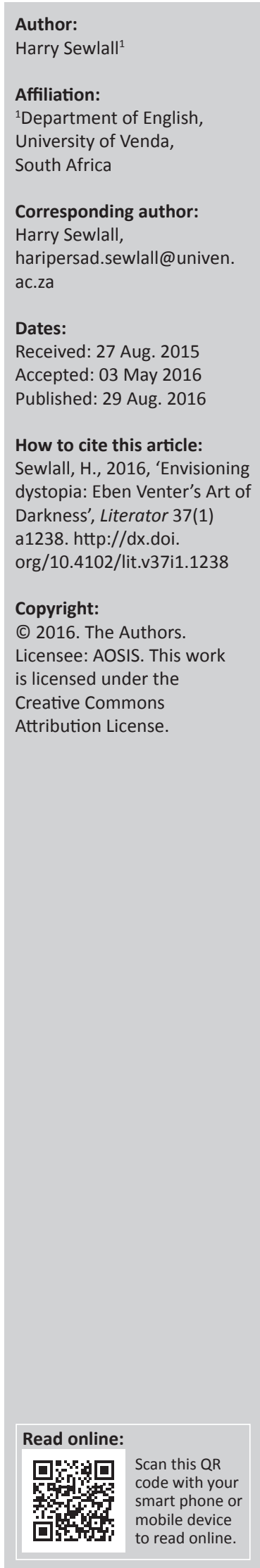

Since the publication of Joseph Conrad's novella Heart of Darkness, published in serial form in 1899, there were several texts that purported to 'rewrite' the Conrad text. Often the relationship with the master text was remote, if not tenuous. Another rewriting of Conrad's text came with the publication of Eben Venter's Trencherman, first published under the Afrikaans title Horrelpoot. This text studiously mimicked the master text not only by using excerpts from it as epigraphs to each chapter, but overtly and covertly wove images and words from the Urtext into its narrative. The questions confronting a reader like myself, who is not conversant with Afrikaans, were whether this was an act of plagiarism or an exercise in intertextuality; or whether this was an act of sensationalism designed to promote sales. These questions formed the basis of an intertextual exploration of both texts. What followed was a close reading of Conrad's text, side-by-side with Trencherman to identify their intertextual links. The theoretical basis was provided by Kristeva and Barthes. The investigation confirmed that Trencherman was indeed an exercise in intertextuality, not simply qua intertextuality but rather as a dialogical engagement with the Conradian master text. The conclusion arrived at was that Trencherman validated itself as an intertextual response to deconstruct the Conrad text and to transpose its scenario to a dystopian, post-democratic South Africa.

Distopie voor oë: Eben Venter se duister kuns. Sedert die verskyning van Joseph Conrad se novelle, Heart of Darkness, uitgegee as vervolgverhaal in 1899, was daar al verskeie pogings om Conrad se teks te 'herskryf', al was die verwantskap met die meesterteks dikwels gering of selfs twyfelagtig. Nog ' $n$ herskrywing van Conrad se teks is Eben Venter se roman Trencherman, aanvanklik in Afrikaans uitgegee as Horrelpoot. Hierdie teks volg die meesterteks baie nougeset na, nie slegs deur aanhalings daaruit as motto's vooraan elke hoofstuk te gebruik nie, maar ook deur beelde en woorde uit die oorspronklike teks op ooglopende of bedekte wyse in die narratief in te weef. Die vrae waarmee 'n leser soos ek, wat nie vertroud is met Afrikaans nie, gekonfronteer word, is of dit 'n geval van plagiaat is of 'n oefening in intertekstualiteit en of die boek eerder ' $n$ poging is om sensasie te wek ten einde meer boeke te verkoop. Hierdie vrae vorm die basis vir 'n intertekstuele verkenning van die twee tekste, wat neerkom op 'n stiplees van Conrad se teks langs Trencherman ten einde die intertekstuele skakels tussen die twee tekste te identifiseer. Teoreties is die artikel gebaseer op die werk van Kristeva en Barthes. Die ondersoek het bevestig dat Trencherman inderdaad 'n oefening in intertekstualiteit is, nie slegs as intertekstualiteit nie, maar eerder as 'n in-gesprek-tree met Conrad se meesterteks. Daaruit volg die slotsom dat Trencherman'n geldige intertekstuele antwoord is op Heart of darkness wat Conrad se beroemde novelle dekonstrueer en die draaiboek daarvan transponeer na ' $n$ distopiese, post-demokratiese Suid-Afrika.

\section{Introduction}

Once in a while texts appear - written or visual - that resonate with Joseph Conrad's controversial novella, Heart of Darkness, first published in serial form in 1899. Sometimes these texts are said to be 'rewriting' Conrad, and at other times they are supposed to be 'responses' to his novella. In the latter case, the relationship with the master text is often remote (Bragard 2008; Eid 2000). As a cinematic text, Apocalypse Now (1979), set in the Vietnam War, is widely acknowledged as a close rewriting of Conrad's urtext. Both the Conrad text and Francis Ford Coppola's re-versioning of it expose the underbelly of imperialism: in the first instance the colonising power is Belgium while in the second it is the United States armed forces in Vietnam from 1955 to 1975. What are we to make of the novel Trencherman by Eben Venter (Venter [2006] 2008), an expatriate South African living in Australia? In this text, originally written in Afrikaans under the title Horrelpoot (2006), ${ }^{1}$

\footnotetext{
1.Regarding the choice of the English title, Eben Venter stated in his interview with Charles Malan:

The possible title Clubfoot seemed too banal, too easy-going for a hard-hitting novel. Trencherman was actually suggested by Gerhard Greyvenstein, our marketing manager. It is an archaic word, intriguing and mysterious. We decided to include its various meanings at the start of the book. Glutton, cadger, carver, knife-wielding ( $\operatorname{man}$ ) man, the rotting trenchfoot, the descent into the hellhole of the trench - all these meanings are evoked by the word trencherman. And all these evocations are intended to illuminate the character of Koert.
} 
a pejorative reference to a club-footed person, we have a protagonist named Marlouw - also an expat South African who reluctantly goes back to South Africa to rescue his nephew whose name is Koert. Although the names 'Marlouw' and 'Koert' are orthographically different from Conrad's protagonists Marlow and Kurtz, it does not take much imagination to conclude that this book is another rewriting of or rejoinder to Conrad's classic tale, especially considering that the author consciously evokes this master text by using extracts from it as epigraphs to each chapter. Russ West-Pavlov's comment on Venter's use of a 'Conradian template' is apposite in this regard: '[This] is intertextuality, not as a secret code or a subtext, but as massive intrusion' (West-Pavlov 2015a:44). How does a reader react to a novel that consciously mimics its predecessor not only by replicating in a slightly disjunctive way the names of its protagonists, or by using excerpts from it as epigraphs, but also by weaving into its narrative fabric lines and images from it? Is Venter engaging in an act of plagiarism or an exercise in intertextuality? If the latter, can his book be considered as a compliment to its famous predecessor? Or are the Conradian resonances merely designed to promote sales? With these questions in mind, this essay attempts to assess the credibility of Venter's intertextual project.

There must be few books that have courted as much controversy as Heart of Darkness written in what Bradbury and McFarlane demarcate as the high Modernist period, which span the years between 1890 and 1930. One of the 'features of the age we are talking about', declare Bradbury and McFarlane, 'is that it is remarkably historicist, disposed to apocalyptic, crisis-centred views of history' (Bradbury and McFarlane [1976] 1991:20). Heart of Darkness was written at the end of the 19th century, a period which ushered in a new century that witnessed, on the one hand, the apogee of human achievement in science, philosophy and technology, and on the other, which also proved to be the most calamitous in human history, bringing with it the two World Wars, the Holocaust, Hiroshima and Nagasaki, and the Vietnam War. It is pertinent, in this regard, to look at the ending of Conrad's fin de siècle novel after Marlow has completed his intense and harrowing account of his journey into the Congo in search of the enigmatic Kurtz. The frame narrator observes:

I raised my head. The offing was barred by a black bank of clouds, and the tranquil waterway leading to the uttermost ends of the earth flowed sombre under an overcast sky - seemed to lead into the heart of an immense darkness. (Conrad [1903] 1927:162)

The moral darkness about to descend on the Western world, emblematised by that tranquil waterway, the Thames, where many an imperial mission began, is reminiscent of Yeats' bleak prognosis in 'The Second Coming', another Modernist literary landmark:

The darkness drops again; but now I know/That twenty centuries of stony sleep/Were vexed to nightmare by a rocking cradle,/And what rough beast, its hour come round at last,/Slouches towards Bethlehem to be born? (Yeats 1950:210-211)
It is no coincidence that Conrad and Yeats, born 8 years apart, envisioned an apocalyptic future that would be marked by moral, social and political upheavals on a scale unprecedented.

A 100 years after Conrad's canonical Heart of Darkness, comes, in the words of West-Pavlov, 'Venter's shrill, hyperbolic nightmare fantasy of a return home to South Africa [which] stages all the worst-case scenarios of post-apartheid South Africa rolled into one' (2015a:43). Translated from the original by Luke Stubbs, Trencherman could be described in a nutshell as a story of an expatriate's journey from Australia to a futuristic, dysfunctional South Africa ravaged by a nuclear explosion and HIV and/or AIDS to find his nephew named Koert. When the protagonist Marlouw (a portmanteau version of his full name, Martin Louw), who reflects physically the club-foot encoded in the original title of the book, Horrelpoot, meets his nephew, all the rumours he has heard about him are confirmed: Koert has become corrupted by the meat empire he has created. Suffering from gangrene, he has become the apotheosis of gluttony, obesity and human excess, or, as Leon de Kock writes in his online review, he is 'the ultimate white anti-whiteman' (De Kock 2009). In Conrad's text, Kurtz is portrayed paradoxically as a genius as well as the devil incarnate, even though 'All Europe contributed' (Conrad [1903] 1927:117) to his making. Venter's character Koert is also portrayed as a gifted individual who transforms into a monstrosity. Both men, the pride of their respective white cultures, become their antithetical selves in their pursuit of wealth. In the climactic moment of the novel, Koert is stabbed to death by some of his followers in an orgiastic ritual. Marlouw manages to escape from the farm and heads back to his adopted country, Australia. When Marlouw meets his sister Heleen, the heartbroken mother of Koert, he confirms his nephew's death - which Heleen had already sensed - but withholds the details of Koert's reprehensible lifestyle and his ignominious death.

Koert had gone back to South Africa to their farm Ouplaas, which, in the dying days of apartheid, the family had ceded over to their workers before emigrating to Australia. Described by his mother as 'bright' and as having a 'mind of his own' (Venter [2006] 2008:3), Koert had stopped communicating with her and she feared that he was desperately ill with no one to look after him in a land ravaged by a 'plague' and which was 'totally out of control' (Venter [2006] 2008:4). Heleen showed Marlouw the last e-mail she had received from her son, in which his language had degenerated into a hybrid of pidgin English, archaisms and gangsta rap:

From here on that is THE option

includin includin

takin responsibility for the people right here, brothers of mine.

The people they needeth me like the earth needeth rain

I'm not scared of making mistakes

I learneth from them cause I made them myself

they give me POWER, can youz feel it?

Koert S₫ieS. (Venter [2006] 2008:24) 
Thus, Eben Venter establishes the central Conradian motif of a journey into Africa to rescue an eccentric maverick. Following the template of its master text, Trencherman traces Marlouw's journey by air and land to find his nephew, who might be gravely ill; and like Charles Marlow in Heart of Darkness, who during the course of his quest learns from various people about Kurtz, the protagonist of Venter's novel learns about Koert from certain characters he meets on his nightmarish journey to the Eastern Cape, where Koert is holed up on the neglected farm Ouplaas. One of Marlouw's informants, a person named Giel whom he meets in Aliwal North, tells him that Koert has established a meat empire - reminiscent of Kurtz's ivory empire in Heart of Darkness:

Let me tell you, that man's sitting pretty. We hear he buys sheep from here all the way to East London. He runs the whole show. There was a story the other day of people who disappeared at his place. But who can prove it? And who cares? Go ask him yourself how he runs his show. One thing's certain: if you want meat around here, go find Koert. (Venter [2006] 2008:99)

This is just one aspect about Koert that Marlouw discovers but similar to the protagonist in Conrad's novella, who is described variously as 'a prodigy', 'an emissary of pity, and science, and progress, and the devil knows what else' (Conrad [1903] 1927:79) there are other aspects about Koert that Marlouw will discover in good time. It has been established by this stage of the story that Koert has a prodigious appetite for whisky, which he orders by the caseful. On one occasion he sends a painting, done by himself, to pay for his whisky. The barman at Aliwal North shows Marlouw the painting:

It's a small sketch in oils of a little girl, draped and blindfolded, walking on an endless surface, something like the salt pans of Namibia, with her hands stretched out in front of her. The sketch is covered in an opaque white layer. (Venter [2006] 2008:101)

Koert's 'small sketch in oils' recalls the painting by Kurtz, as described in Conrad. When Marlow is about to leave the room of the sly brickmaker who has been trying to elicit information from him, he notices:

a small sketch in oils, on a panel, representing a woman, draped and blindfolded, carrying a lighted torch. The background was sombre-almost black. The movement of the woman was stately, and the effect of the torch-light on the face was sinister. (Conrad [1903] 1927:79)

On an intertextual level, the paintings are echoes of each other. But there is a difference in their theme and execution. In the Conrad novella where images of light and darkness are paradoxically deployed, the lighted torch symbolises the enlightenment that colonisation is purported to bring to colonised people. In Venter's text, there is no such pretence at enlightenment. There is no torch of hope. What is represented is an unrelenting, bleak landscape in which the little girl (contrasting with the mature woman in the proto-text) is trying to find her way, similar to Marlouw's blind quest for his nephew.
When Marlouw finds himself on the farm Ouplaas, it takes a while before he can actually see his nephew, who is protected by his mistress and his henchmen - once again, an echo of the plot of Heart of Darkness. It is only on page 239, with about 80 pages to go before the end of the book, that Marlouw meets Koert. What he encounters is not that athletic young man he once knew but a monstrosity:

The flesh of all flesh rises in front of me, flesh consumed by flesh that has multiplied and swollen into a malformed colossus of human dough with pink folds hanging from its sides. The giant rounding of the shoulders, the ox-like shoulder blades that shimmer with the secretions of fattiness, the droop of the breasts, the belly that shudders and is stretched to bursting point at the navel. (Venter [2006] 2008:239)

By now Marlouw has been prepared for this obscenity. In the manner of what Ian Watt has referred to as Conrad's 'delayed decoding' (Watt 1980:279), a day before Martin Louw is permitted to see his nephew, he comes across a mysterious woman on a horse - a woman who claims to have been his late father's mistress - who tells him:

Who do you think you've come here to see, Marlouw? A high school boy who blushes when he touches a girl's breasts for the first time? ... Let me tell you what you've come to find here: a colossal monster. A man who lacks restraint in the gratification of his vile desires. (Venter [2006] 2008:219)

These echoes from Heart of Darkness are a few of the multiple instances where Venter's novel reflects its master text. The motif of 'restraint' appears in Heart of Darkness when Marlow ponders why the black crew of 30 men do not overpower the five white men and devour them considering that have little to eat: 'Restraint! What possible restraint? Was it superstition, disgust, patience, fear - or some kind of primitive honour? No fear can stand up to hunger, ...' (Conrad [1903] 1927:105). Compared to the primitive cannibals, Mr. Kurtz 'lacked restraint in the gratification of his various lusts, ...' (Conrad [1903] 1927:131). Transposed to Venter's novel, the motif of restraint throws into relief the enormity of Koert's transgressions.

\section{The ultimate white anti-whiteman}

In his review of Trencherman, Leon de Kock writes:

Koert is possibly one of the most grotesque and fascinating fictional figures I have yet encountered in a South African work of imaginative writing. He is an abomination, a demi-god, the apogee of inward fear and horror. Physically, he is a malformed, obese and sweating Hulk who spits vengeance, largesse and crazy intelligence by turns. He is the ultimate white antiwhiteman. His repulsiveness knows no bounds. (De Kock 2009)

The misguided notion of white Afrikaner supremacy was one of the cornerstones on which the ideology of apartheid was constructed. If the white Afrikaner perceived himself as the epitome of perfection, Venter's Koert, according to Leon de Kock, seems to represent another image of the last surviving Afrikaner, namely, a debased individual, the very antithesis of a civilised being. Once again, the comparison with Kurtz is inescapable. 
Like Conrad's protagonist, Koert has no desire to go back to civilisation. Holed up in his quarters where he keeps a chamber-pot under his bed, the gangrenous and smelly Koert passes his time playing Mario Kart, a Nintendo game, and drinking Bells whisky. And like Conrad's Mr Kurtz, this white man has 'gone native'. For female companionship, he has Esmie Phumzile, who shows all the symptoms of an HIV and/or AIDS sufferer. In a heart-rending scene later, when she implausibly begs Marlouw to take her away to Australia, she claims to be carrying Koert's child. Unlike Kurtz's 'mute' mistress whose anguish at her dying lover's departure is expressed by the gesture of her raised arms, Esmie Phumzile is invested with agency and a voice of her own - once more a nuanced, intertextual gesture that serves to compliment and complement its predecessor.

The sick Koert embodies the plague that follows the nuclear explosion at Koeberg. Hunger, disease and drought, attended by lawlessness and chaos, stalk the land. Now that he is ill and no longer able to dispense meat and whisky to his sycophantic followers as he used to, he has served his purpose and his end is imminent. And the end does come when a huge, orgiastic party is held around a fire on the last night of Marlouw's stay. Koert is brought to the party by his consort Esmie. Using his scuffed elbows, he crawls towards the fire around which the crowd dances to the beat of a drum. The act of crawling is meant to resonate with the word 'crawl' in its various permutations in Heart of Darkness: as when Marlow and his crew crawl up the river; or when the dying natives crawl away into the bush to die; or when the sick Mr Kurtz crawls away from the steamer when trying to escape from Marlow and his crew. The image of crawling, common to both Kurtz and Koert, embodies the dehumanisation that afflicts both the conqueror and the conquered.

Why does Koert come in this condition to the party? The narrative voice proclaims because he 'is the authentic white master. The one who enforces his will to the bitter end. Without knowing it, that's what he'd come here to be' (Venter [2006] 2008:298). Goaded on by the old witch who calls Koert a 'mzungu' (a Swahili word referring to someone who wanders without purpose (Urban Dictionary), who has 'devoured all the meat on this farm' (299), a man in a balaclava steps up to Koert, surreptitiously produces a knife and plunges it into Koert's soft belly. In ritualistic fashion the knife is passed to other men in balaclavas and each 'drives the knife cleanly and accurately into the flesh of the master' (Venter [2006] 2008:302). In his death throes Koert utters a last mighty cry: 'De horror. I am de horror' and falls on his face in the pool of his blood. This is the ultimate parody of Heart of Darkness with Kurtz's eternally enigmatic 'The horror! The horror!' transposed into a pedestrian, if not laughable, 'I am de horror'. (This scene alone warrants a film script of the book, which, incidentally, became available in Britain in 2016, a decade after its original publication in Afrikaans.)

Marlouw manages to escape from the assassins and finds himself eventually in the city of Melbourne where he visits his sister Heleen. Although Marlouw does not tell her about Koert's condition or his manner of death, she senses that he is dead. When she asks Marlouw if Koert mentioned her name before he died, Marlouw replies, 'He was already very far gone, you must understand, Heleen. All sorts of words came out of his mouth. You could almost say bubbled out. And yes, one of those words was your name' (Venter [2006] 2008:312-313). Marlouw then narrates, 'I get up quickly and step away from her and my white lie and try, without success, to forgive myself" (Venter [2006] 2008:313). Coming towards the end of the novel, this lie that Marlouw tells his sister Heleen is the last of the self-conscious devices that Venter has used to echo Heart of Darkness when Marlow, in response to Kurtz's fiancée's importunate request to know what her betrothed said before he died, says 'The last word he pronounced was - your name' (Conrad [1903] 1927:161).

The presence of Conrad's urtext is ubiquitous - sometimes as an elaborate trope and at other times in a word or phrase casually dropped by Marlouw or the frame narrator. Here is one example of the latter: when Marlouw is obstructed by Koert's retainers from seeing his nephew, he expresses his frustration and tells of the tedious routine on the farm in the following manner: 'I await an opportunity to speak to Koert, but am repeatedly prevented. Camp, cook, sleep, strike camp, march. My life is reduced to a primitive existence ...' (Venter [2006] 2008:176). In Heart of Darkness, Marlow narrates: 'Day after day, with the stamp and shuffle of 60 pair of bare feet behind me, each pair under a $60 \mathrm{lb}$. load. Camp, cook, sleep, strike camp, march' (Conrad [1903] 1927:71). What are we to make of such self-conscious textual resonances, or as West-Pavlov puts it, the 'ostentatious use of chapter epigraphs ... not to mention a relentless flow of textual allusions, some of them explicitly recursive' (WestPavlov 2015a:44)?

\section{Intertext, pretext or plagiarism?}

At this juncture the tentative questions posed in the abstract of this essay will be addressed briefly. The crux of the set of questions is whether Venter's text is an act of plagiarism or a work of intertextuality, or whether it is a sensational marketing ploy. Considering that the author acknowledges at the end of the book that certain 'characters, scenes and sentences in the text are reinterpretations' of Conrad's original text, the charge of plagiarism would be spurious. Considering too that the original title was Horrelpoot and the English version Trencherman - none of them remotely suggesting any kinship with the Conrad text - coupled to the fact that Venter's original project was targeted at a limited readership, namely, the Afrikaner reader and/or intellectual in South Africa and in the rest of the Afrikaner diaspora, it is quite clear that the writer has eschewed sensationalism and commercial interests in favour of artistic integrity. One Afrikaner academic, reviewing Horrelpoot in a newspaper, has nothing but praise for it: 'An ingenious blend of internal monologue, dialogue, dreams and retrospective narratives, the novel is evidence of Venter's astonishing writing ability. 
With Horrelpoot, Venter has reached a high point' (Willie Burger, quoted in the flyleaf of the English edition). Those readers whose command of language is limited to English would only have been alerted to Trencherman as a re-working of Conrad by bilingual critics and academics such as Leon de Kock and Dawid de Villiers. The only inference then is that Venter intended his text to be an adaptation of Heart of Darkness to serve as a chronicle of what white South Africans, in the main, would regard as an impending apocalypse brought about by a dysfunctional government. Like the Conrad text, which proleptically serves as a harbinger of a troubled century, Venter's novel falls into a continuum of narratives on the circularity of universal contretemps.

Reading Conrad and Venter dialogically in a spatio-temporal trajectory would be consonant with what Russ West-Pavlov has postulated in his trenchant study of Heart of Darkness and its 'avatars' as a 'chronotope'. Deploying Bakhtin's precept of the chronotope, he contends:

In analogy with the Bakhtinian notion of the chronotope, I will argue that Heart of Darkness and its avatars themselves constitute a chronotope, a spatio-temporal complex whose trajectory around the globe and down the twentieth century into the twenty-first itself forms a complex story never yet told in its full scope. (West-Pavlov 2015b:54)

Intertextuality, or adaptation, as Linda Hutcheon (with Siobhan O'Flynn) avers, is not necessarily harmful to the original source:

An adaptation is not vampiric: it does not draw the life blood from its source and leave it dying or dead, ... It may, on the contrary, keep that prior work alive, giving it an afterlife it would never have had otherwise. (Hutcheon [2006] 2013:176).

While the latter part of the foregoing quotation does not apply to Conrad's novella, which has been granted immortality by the academic and publishing industry, an adaptation such as Trencherman raises the issue of the latter's use of intertextuality and its relationship with the master text.

Texts speaking to other texts is not only a phenomenon of postmodern writing but something that goes back to the very foundations of Western literature. According to María Jesús Martínez Alfaro (1996:269) this practice can be traced back to Plato: 'Bakhtin himself locates in the Socratic dialogues one of the earliest forms of what he terms variously the novel, heteroglossia, dialogism - what Kristeva will christen intertextuality'. Pioneering scholars such as Bakhtin, Kristeva and Barthes have pointed out that texts are not time-bound but stretch across ages and cultures. In his celebrated essay 'The Death of the Author', Barthes touches on the central notions of dialogic exchange, parodic mimicking and contestation in intertextuality: '[A] text is made of multiple writings, drawn from many cultures and entering into mutual relations of dialogue, parody, contestation ...' (Barthes 1977:148). In an online review of Trencherman in July 2008, Dawid de Villiers writes:

We must not lose sight, however, of the grim humour involved in Venter's portrayal. Both Kurtz and Koert may be figures of hubris, and both may at times come across as pathetic rather than portentous, but the latter has sole claim to being also grotesquely comical - from his linguistically encompassing gibberish to his bulbous body he is literally an exaggeration of Kurtz - in short, a parody. What could such a parody mean? Generally speaking, a parody simultaneously critiques another text (usually canonical) and acknowledges its strength - in such general terms, then, Venter confirms the eminence of Heart of Darkness as a novel dealing with the confrontation between Europe and Africa, while possibly suggesting that its perspective is no longer reflective of current or imminent realities. (De Villiers 2008)

Although De Villiers does not mention the term 'intertextual' in his four-page review, he draws several parallels with the Conrad text, pointing to their intertextual resonances, convergences and divergences. He goes so far as to suggest that at times Venter:

approaches Heart of Darkness via Coppola's reimagining of it in Apocalypse Now ... even the concept of an overweight Kurtz figure and the fact he dies by violence, recall Coppola's film rather than Conrad's novel. (De Villiers 2008).

Leon de Kock's earlier review of 23 March 2009 also eschews the term 'intertextual' although it recognises Venter's novel as 'a deliberate rewriting of Joseph Conrad's Heart of Darkness' (De Kock 2009). It is at the level of the intertextual, and thus the symbolic and allegorical, that Trencherman makes its unique impact as a study of the angst of the white Afrikaner community in a post-apartheid South Africa. An important insight offered by Kristeva is the subversive potential of intertextuality, or 'transposition' as she preferred to call it, to discourage the banal reading of a study of sources: '[W]e prefer the term transposition because it specifies that the passage from one signifying system to another demands a new articulation of the thetic - of enunciative and denotative positionality' (1984:59). Venter's re-conceptualising and rewriting of Conrad conforms to Kristeva's enabling insight into the subversive nature of intertextuality. When Charles Malan, who interviewed Venter in October 2008, turned to the inevitable comparison with Conrad, the author's response was:

Through their language, their empowerment and humanity and the assimilation of Marlouw with the black people I intended to write a corrective on the one-dimensional portrayal of black people in Conrad's novel. (Charles Malan).

This is not the place to take issue with Eben Venter's rehearsal of the charge that Conrad's characters are one-dimensional, suffice to say that what Conrad created was not a novel in the conventional sense but a dramatic monologue-Marlow's monologue - certainly with its stereotypes of black people, gender insensitivities and racially-offensive descriptors but arguably the most devastating anti-colonial critique in the English canon. In Trencherman, what Venter has created is a completely 'new' dialogic text, a novel, peopled with characters invested with agency. Using the Conradian text as a template, Venter has shaded in his own plot, setting, characterisation and symbology. To illustrate, in Conrad's 
Heart of Darkness, Marlow sees two women knitting when he visits his aunt in Brussels:

Two women, one fat and the other slim, sat on straw-bottomed chairs, knitting black wool. The slim one got up and walked straight at me-still knitting with down-cast eyes ... (Conrad [1903] 1927:55).

Much later, in Africa, Marlow remembers these women:

Often far away there I thought of these two, guarding the door of Darkness, knitting black wool as for a warm pall, one introducing, introducing continuously to the unknown, the other scrutinizing the cheery and foolish faces with unconcerned old eyes. (Conrad [1903] 1927:57)

Eben Venter makes capital of this knitting scene. When Marlouw visits his sister, who is out at the moment, he sees the maid Jocelyn on one of the stools at the breakfast counter:

There's knitting on her lap and she picks up what she'd apparently been doing when I rang the bell ... The wool is black, and she's finished a gigantic piece. It tumbles between her legs and falls in loads onto the sterile kitchen floor. (Venter [2006] 2008:14)

This image of the black wool is taken up several pages later when Heleen returns to her flat:

Slowly, like tar being poured, the black knitting slips from her lap and falls misshapen on the floor. The dog suddenly realizes there's a river of black knitting between him and his mistress and tries to wade through it: each time he tries to get free the wool makes waves and entangles him even more. We all look down at Henrie drowning in Jocelyn's wool. The dog wails like a baby. (Venter [2006] 2008:25)

In Kristevaean terms, the black wool has taken on an ominous symbolism that finds a resonance in the old thetic position (Heart of Darkness) and the formation of a new one (Trencherman). It is now a 'river' of black knitting, reminding us of Marlow's crew that will crawl up the River Congo to Kurtz's Inner Station. Unlike Conrad's Marlow, the clubfooted Marlouw in Trencherman will make his way towards the farm Ouplaas in a bakkie, but like the dog Henrie that gets tangled in the black wool in this scene, Marlouw will find himself entangled in the warp and weft of Koert's phantasmagorical world.

To plead guilty to the charge of what Wimsatt and Beardsley referred to as the 'Intentional Fallacy', it would be instructive to listen to the voice of Eben Venter. When questioned by Charles Malan about his controversial depiction of the 'apocalyptic South African collapse' in his book, the novelist replies:

In the past year or so there has been a spate of dystopic novels: The Road by Cormac McCarthy, The Eagle's Throne by Carlos Fuentes ... I believe Trencherman taps into a similar Zeitgeist and gains relevancy by doing so. (Charles Malan)

In the same interview he declares, 'It is this utter devotion to South Africa that has made me write about the total destruction of my people, my language and my country' (Charles Malan).

\section{Conclusion}

As a conscious re-enactment of the ur- or master text by Conrad, Trencherman deserves a place in the archive of Conradiana if for no other reason than that it raises pertinent questions about the post-democratic South Africa and its much-vaunted Constitution. Like Conrad's text, Venter's project has the potential to generate controversy in the way that Heart of Darkness has, and the way J.M. Coetzee's Disgrace did in its bleak evocation of the new South Africa. Although Heart of Darkness and Trencherman belong to two distinct genres of writing - one located in the tradition of realism and the other in the tradition of futuristic, dystopian writing - they are both controversial texts in their own ways. Heart of Darkness has received more than its fair share of negative criticism from scholars in Africa and abroad since Achebe's notorious denunciation of the writer as a 'thoroughgoing racist' in a lecture in 1975 (Achebe 1988:257), subsequently revising these words to 'bloody racist' (Achebe 1990:124) 2 years later in The Massachusetts Review, 18:4, 782-794. Notwithstanding Achebe's criticism of Conrad, the late Eloise Knapp Hay, the doyenne of early Conrad scholarship, described Heart of Darkness as a 'vehement denunciation of imperialism and racialism' (Hay [1963] 1981:112).

Cedric Watts has said of Heart of Darkness: 'It offered a concise iconography of modern corruption and disorder. The tale became an anthology of epitomes' (Watts [1987] 2008:24). In the light of Watts's comment, Venter's use of Conrad's template to envision a futuristic South Africa is a compelling testimony to the relevance of Conrad's novella. If the power of intertextuality resides in its potential to enable excursions into texts across linguistic, national and ideological frontiers with a view to interrogating, deconstructing or subverting them through caricature and parody, then Trencherman validates itself as a rewriting of Heart of Darkness to present the reader with a troubling vision of a dystopian society.

\section{Acknowledgements}

The author acknowledges the financial support of the National Research Foundation (NRF - South Africa) under whose aegis his research is conducted. The views expressed are his own and in no way reflect the policy or views of the NRF.

\section{Competing interests}

The author declares that he has no financial or personal relationships which may have inappropriately influenced him in writing this article.

\section{References}

Achebe, C., 1988, 'An image of Africa: Racism in Conrad's Heart of Darkness', in R. Kimbrough (ed.), Joseph Conrad: Heart of darkness, pp. 251-262, W. W. Norton, New York.

Achebe, C., 1990, 'An image of Africa', in R.D. Hamner (ed.), Joseph Conrad: Third world perspectives, pp. 119-129, Three Continents Press, Washington, DC.

Alfaro, M.J.M., 1996, 'Intertextuality: Origins and development of the concept', Atlantis 18(1/2), 268-285, viewed 5 June 2013, from http:www.jstor.org/stable/ 41054827 
Barthes, R., 1977, 'The death of the author', in R. Barthes (ed.), Image music text, transl. S. Heath, pp. 142-148, Fontana Paperbacks, London.

Bradbury, M. \& McFarlane, J., [1976] 1991, 'The name and nature of modernism', in M. Bradbury \& J. McFarlane (eds.), Modernism: A guide to European literature 1890-1930, pp. 19-56, Penguin, London.

Bragard, V., 2008, “'Uncouth sounds” of resistance: Conradian tropes and hybrid epistemologies in Pauline Melville's The Ventriloquist's Tale', Journal of Postcolonial Writing 44(4), 415-425.

Conrad, J., [1903] 1927, Youth and two other stories, Malay Edition, Doubleday, New York.

De Kock, L., 2009, 'Eben Venter's Trencherman reviewed by Leon de Kock', Kagablog March 23, viewed 28 May 2014, from http://kaganof.com/kagablog/2009/ 03/23eben-venter's-trencherman-reviewed-by-leon-de-kock

De Villiers, D., 2008, 'Trencherman: Venter's anatomy of visionlessness in translation' LitNet 28 July, viewed 28 May 2014, from http://www.litnet.co.za/trenchermanventer-s-anatomy-of-visionlessness-in-translation

Eid, H., 2000, 'Naipaul's a bend in the river and neo-colonialism as a comparative context', CLCweb: Comparative Literature and Culture 2(3), Article 7, viewed 28 May 2014, from http://docs.lib.purdue.edu/clcweb

Hay, E.K., [1963] 1981, The political novels of Joseph Conrad: A critical study, The University of Chicago Press, Chicago, IL.
Hutcheon, L., with O'Flynn, S., [2006] 2013, A theory of adaptation, 2nd edn., Routledge, London.

Kristeva, J., [1974] 1984, Revolution in poetic language, transl. M. Waller, with an Introduction by L.S. Roudiez, Columbia University Press, New York.

Malan, C., 2008, 'Interview: Eben Venter's Trencherman', LitNet, 15 October, viewed 28 May 2014, from http://www.litnet.co.za/interview-eben-venter-s-trencherman

Urban Dictionary, 'Definition of “Mzungu”', viewed 26 April 2016, from http://www. urbandictionary.com

Venter, E., [2006] 2008, Trencherman, Tafelberg, Cape Town.

Watt, I., 1980, Conrad in the nineteenth century, Chatto \& Windus, London, p. 279.

Watts, C., [1987] 2008, 'Heart of darkness', in H. Bloom (ed.), Bloom's modern critical interpretations: Joseph Conrad's heart of darkness, pp. 19-35, Infobase Publishing, New York.

West-Pavlov, R., 2015a, 'Apocalypse now, never ... or forever: Venter and Medalie on the everyday politics of post-apartheid South Africa', English Studies in Africa 58(1), 42-55.

West-Pavlov, R., 2015b, 'Heart of darkness as chronotope: Conradian avatars in fiction, criticism, publishing and pedagogy', in G. Fincham, J. Hawthorn \& J. Lothe (eds.), Outposts of progress: Joseph Conrad, modernism and post-colonialism pp. 49-71, UCT Press, Cape Town.

Yeats, W.B., [1933] 1950, The collected poems of W. B. Yeats, Macmillan, London 